\title{
Reactivity of 3-substituted pyrazole-5-diazonium salts towards 3-azolyl enamines. Synthesis of novel 3-azolylpyrazolo- $[5,1-c][1,2,4]$ triazines
}

\author{
Daria L. Alexeeva, ${ }^{a}$ Elena V. Sadchikova, ${ }^{\text {a }}$ Natalia N. Volkova, ${ }^{a}$ Ilya V. Efimov, ${ }^{\text {a }}$

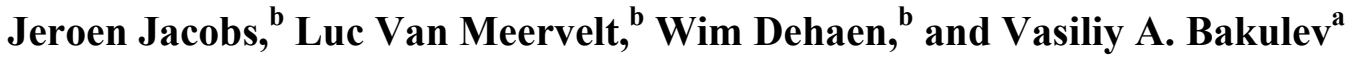 \\ ${ }^{a}$ Institute of Chemical Technology, The Ural Federal University named after the first President \\ of Russia B.N.Yeltsin, Mira str. 28, Yekaterinburg, 620002, Russia \\ ${ }^{b}$ Department of Chemistry, Celestijnenlaan 200F, KU Leuven, B-3001 Leuven, Belgium \\ E-mail: e.v.sadchikova@urfu.ru
}

DOI: http://dx.doi.org/10.3998/ark.5550190.p009.571

\begin{abstract}
A series of novel 3-azolylpyrazolo[5,1-c][1,2,4]triazines was synthesized by reaction of 3 -substituted pyrazole-5-diazonium salts with $\beta$-azolyl enamines in an efficient fashion. The structures of the compounds prepared were characterized by NMR spectroscopy, massspectrometry, elemental and X-ray diffraction analyses. Plausible mechanisms were formulated.
\end{abstract}

Keywords: 3-Substituted pyrazole-5-diazonium salts, enamines, pyrazolo[5,1-c][1,2,4]triazines

\section{Introduction}

Heterocyclic diazo compounds and the corresponding diazonium salts represent an important class of organic compounds due to their wide spectrum of reactivity in diverse reaction types. Similar to aromatic diazonium salts, they can couple with a very broad range of aromatic and heteroaromatic compounds ${ }^{1,2}$ as well as with active methylene reagents ${ }^{3-6}$ to form azo compounds and hydrazones, respectively. On the other hand, similarly to diazoalkanes, they react with alkenes, ${ }^{7-14}$ alkynes, ${ }^{8-10}$ enamines, ${ }^{10,12,13,15}$ ynamines, ${ }^{7,12,13,16}$ isocyanates ${ }^{17-23}$ and isothiocyanates $^{24,25}$ to furnish a huge variety of heterocyclic compounds. Thus, heterocyclic diazo compounds are important building blocks in organic synthesis and can be used as key precursors in the synthesis of various derivatives.

We turned our attention to reactions of diazopyrazoles 1 with enamines because they take place in a regioselective manner to form pyrazolo[5,1-c][1,2,4]triazines as exclusive products in good yields. Scheme 1 shows a few known examples for formation of pyrazolotriazines $\mathbf{2}-\mathbf{4}$ by this reaction. ${ }^{10,12,13,15}$ 
To the best of our knowledge 3-azolylpyrazolo[5,1-c][1,2,4]triazines are not described in the literature and reactions of $\beta$-azolyl enamines with diazo compounds and diazonium salts are not studied so far. At the same time both pyrazolotriazines and azoles, such as 1,2,3-thiadiazoles and isoxazoles, exhibit interesting biological and chemical properties. ${ }^{26-32}$ Therefore, it is a challenging task to develop a new efficient synthetic method for their preparation. In continuation of our interest in the chemistry of diazoazoles and the synthesis of various types of triazines we have carefully studied the reactions of 3-substituted pyrazole-5-diazonium salts with enamines containing heterocyclic components.

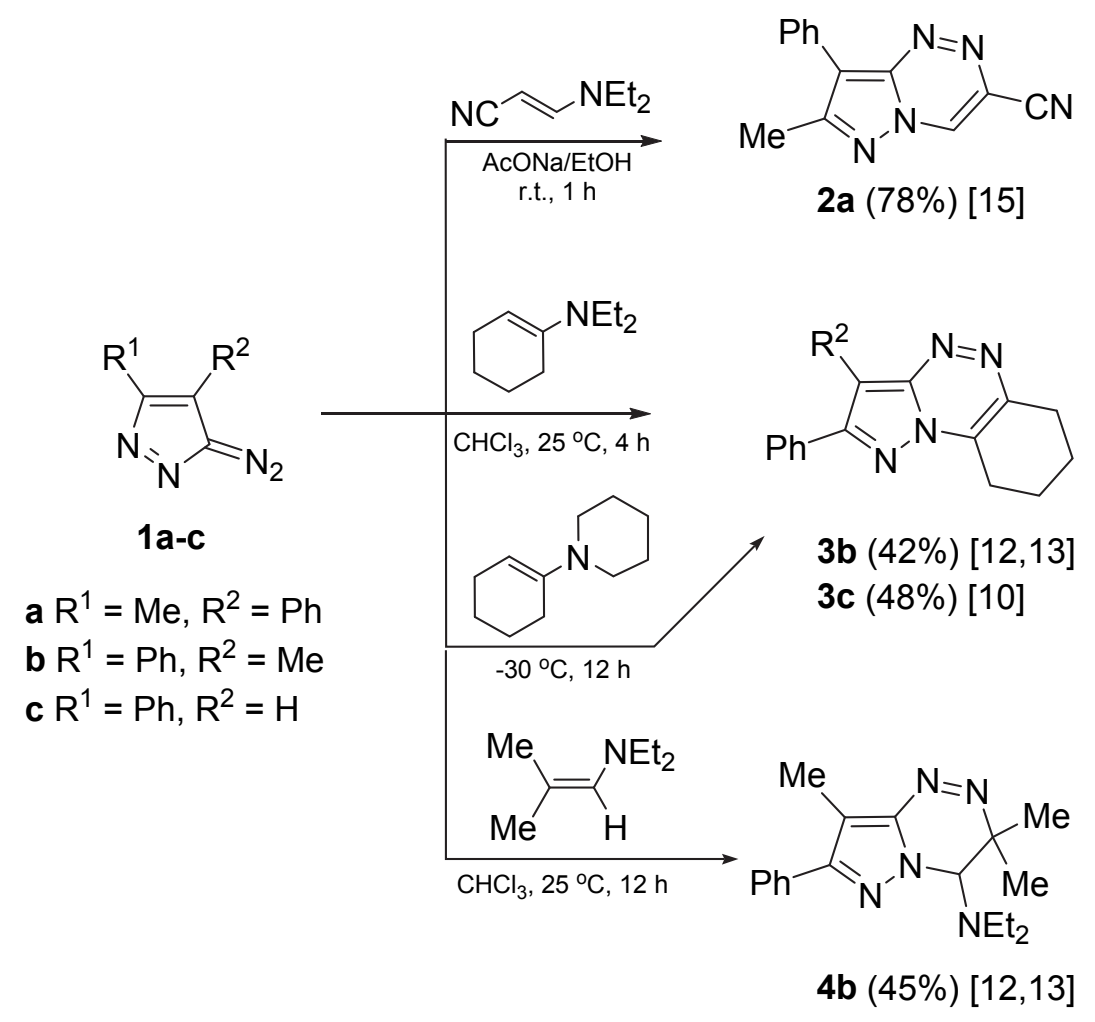

Scheme 1. Known examples for reaction of diazopyrazoles 1a-c with enamines.

\section{Results and Discussion}

In the current research we have studied the reaction of 3-substituted pyrazole-5-diazonium salts 6a-e with enamines 8a-f containing isoxazole and thiadiazole moieties and found that this leads to the formation of pyrazolo[5,1-c][1,2,4]triazines 9a-l.

To prepare pyrazole-5-diazonium salts 6a-d we treated 3-aryl-1H-pyrazole-5-amines 5a-d with sodium nitrite and sulfuric acid in water solution at $0-5{ }^{\circ} \mathrm{C}$. The desired compounds 6a-d were prepared in good yields as solid substances. In the case of 3-methyl-1H-pyrazole-5-amine 5e we did not manage to isolate hydrosulfate salt $\mathbf{6 e}$ as a solid. Therefore, it was alternatively 
generated from aminopyrazole $\mathbf{5 e}$ by reaction with sodium nitrite in an aqueous solution of $\mathrm{HBF}_{4}$ at low temperature (Scheme 2) and tetrafluoroborate salt $\mathbf{6 e}$ was used in situ in further studies.
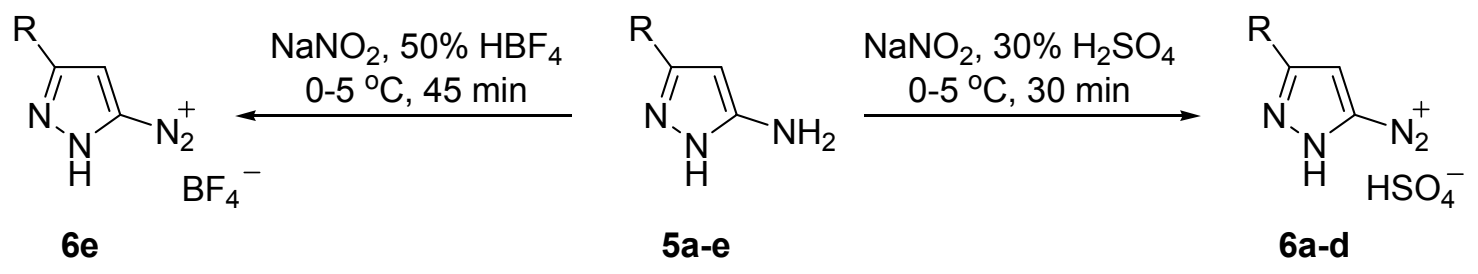

5,6a R = Ph; 5,6b R = 4-Tol; 5,6c R = 4-MeOC ${ }_{6} \mathrm{H}_{4} ; \mathbf{5 , 6 d ~ R}=4-\mathrm{ClC}_{6} \mathrm{H}_{4} ; \mathbf{5 , 6 e} \mathrm{R}=\mathrm{Me}$

Scheme 2. Diazotization of 3-substituted 5-amino-1H-pyrazoles 5a-e.

Enamines 8a-f were prepared by treatment of the corresponding 5-methylthiadiazole-4carboxylate 7a,b or alkyl 5-methyl-3-arylisoxazole-4-carboxylates esters 7c-f with DMF-DMA in the presence of $N$-methylimidazole under reflux for six hours as has been reported earlier ${ }^{33,34}$ (Scheme 3).

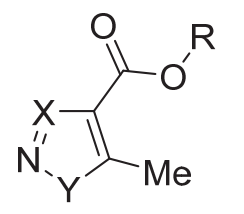

7a-f

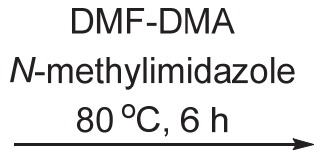

8a-f

$\mathbf{7 , 8} \mathbf{a}, \mathbf{b} X=\mathrm{N}, \mathrm{Y}=\mathrm{S}, \mathbf{a} \mathrm{R}=\mathrm{Et}, \mathbf{b} \mathrm{R}=\mathrm{Me}$

7,8 c,d $X=P h-C, Y=O, c R=M e, d R=E t ;$

7,8 e $X=2-\mathrm{Cl}-6-\mathrm{FC}_{6} \mathrm{H}_{3}-\mathrm{C}, \mathrm{Y}=\mathrm{O}, \mathrm{R}=\mathrm{Me}$;

7,8 f X $=3-\mathrm{FC}_{6} \mathrm{H}_{4}-\mathrm{C}, \mathrm{Y}=\mathrm{O}, \mathrm{R}=\mathrm{Et}$

Scheme 3. Synthesis of known 3-azolyl enamines 8a-f.

Then with diazonium salts 6a-e and azolyl enamines 8a-f in hands we studied the reaction of 3-substituted pyrazole-5-diazonium salts 6a-e with azolyl enamines 8a-f (Scheme 4) and optimized the reaction conditions (Table 1). 


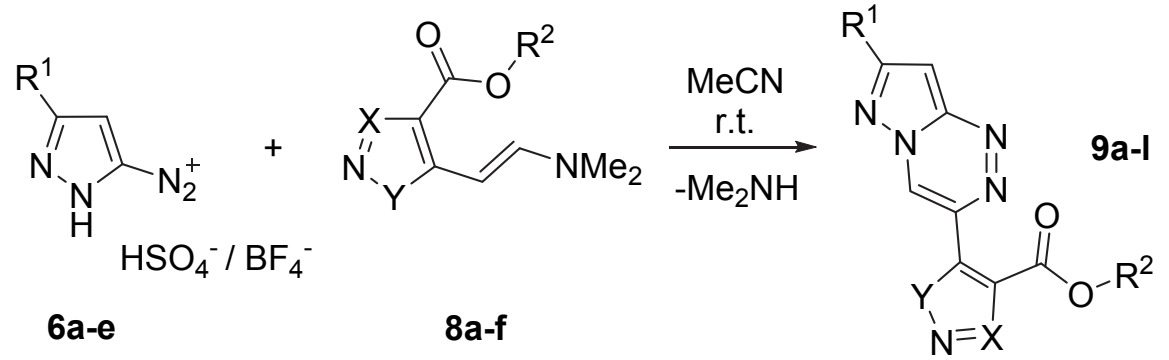

Scheme 4. Synthesis of 3-azolylpyrazolo[5,1-c][1,2,4]triazines 9a-I.

The study of the progress of the reaction mixture indicated that homogenous conditions were superior to heterogeneous ones (compare entries 2, 3 with entry 1). From the solvent screening it was found that acetonitrile was the best solvent (compare entry 3 with entries 1, 2 and entry 10 with entry 9). Furthermore, room temperature conditions performed better than heating at 45-50 ${ }^{\circ} \mathrm{C}$ (compare entries 3,10,14 with entries 4,11,15, respectively). Based on the low yields of the title compounds at $50{ }^{\circ} \mathrm{C}$, the partial decomposition of the initial diazo compounds was assumed due to the temperature increase. Good yields of the desired pyrazolo[5,1-c] $[1,2,4]$ triazines 9 were obtained when the reaction was performed in acetonitrile at room temperature and these conditions were chosen as the optimal ones.

We have found the regioselective formation of novel 3-azolylpyrazolo[5,1-c][1,2,4]triazines 9a-l in good to excellent yields (Table 1).

Table 1. Characteristics of 3-azolylpyrazolo[5,1-c][1,2,4]triazines 9a-l

\begin{tabular}{|c|c|c|c|c|c|}
\hline Entry & Compds. & Product & $\begin{array}{l}\text { Time } \\
\text { (h) }\end{array}$ & $\begin{array}{c}\text { Yield* } \\
(\%)\end{array}$ & $\operatorname{Mp}\left({ }^{\circ} \mathrm{C}\right)$ \\
\hline $\begin{array}{l}1 \\
2 \\
3 \\
4\end{array}$ & $9 a$ & & $\begin{array}{c}4^{\mathrm{a}} \\
2^{\mathrm{b}} \\
1.5^{\mathrm{c}} \\
0.75^{\mathrm{d}}\end{array}$ & $\begin{array}{l}46 \\
48 \\
65 \\
44\end{array}$ & $180-181$ \\
\hline 5 & $9 b$ & & $1.5^{\mathrm{c}}$ & 71 & 194-195 \\
\hline
\end{tabular}


Table 1. Continued

\begin{tabular}{|c|c|c|c|c|c|}
\hline Entry & Compds. & Product & $\begin{array}{c}\text { Time } \\
\text { (h) }\end{array}$ & $\begin{array}{c}\text { Yield* } \\
(\%)\end{array}$ & $\mathrm{Mp}\left({ }^{\circ} \mathrm{C}\right)$ \\
\hline 6 & $9 c$ & & $3.5^{\mathrm{c}}$ & 70 & $177-178$ \\
\hline 7 & 9d & & $2.5^{\mathrm{c}}$ & 67 & $245-246$ \\
\hline 8 & $9 e$ & & $1.2^{\mathrm{e}}$ & 73 & $244-245$ \\
\hline 9 & & & $2.5^{\mathrm{b}}$ & 53 & \\
\hline 10 & 9f & & $1.5^{\mathrm{c}}$ & 64 & $232-233$ \\
\hline 11 & & & $0.8^{\mathrm{d}}$ & 31 & \\
\hline 12 & $9 g$ & & $2.5^{\mathrm{c}}$ & 70 & $242-243$ \\
\hline 13 & $9 h$ & & $2.5^{\mathrm{c}}$ & 57 & $230-231$ \\
\hline
\end{tabular}


Table 1. Continued

Entry Compds.

* Isolated yields of pyrazolotriazines 9 in two step process: $\mathbf{5} \rightarrow \mathbf{9}$

${ }^{\mathrm{a}} \mathrm{CHCl}_{3}, \mathrm{rt} ;{ }^{\mathrm{b}}$ Pyridine, $\mathrm{rt} ;{ }^{\mathrm{c}} \mathrm{MeCN}, \mathrm{rt} ;{ }^{\mathrm{d}} \mathrm{MeCN}, 45-50{ }^{\circ} \mathrm{C} ;{ }^{\mathrm{e}} \mathrm{MeCN}, \mathrm{Na}_{2} \mathrm{CO}_{3} / \mathrm{H}_{2} \mathrm{O}$, rt

According to literature, we suggest three plausible mechanisms for the formation of the 3azolylpyrazolo[5,1-c][1,2,4]triazines 9a-l (Scheme 5). Compounds 9a-l are assumed to be formed via coupling at $\mathrm{C}-2$ of the activated double bond of enamines 8a-f with the diazonium ions of 6a-e to afford the azo intermediates $\mathbf{I}$ that undergo intramolecular cyclization via elimination of dimethylamine to final compounds 9 . $^{35}$ 


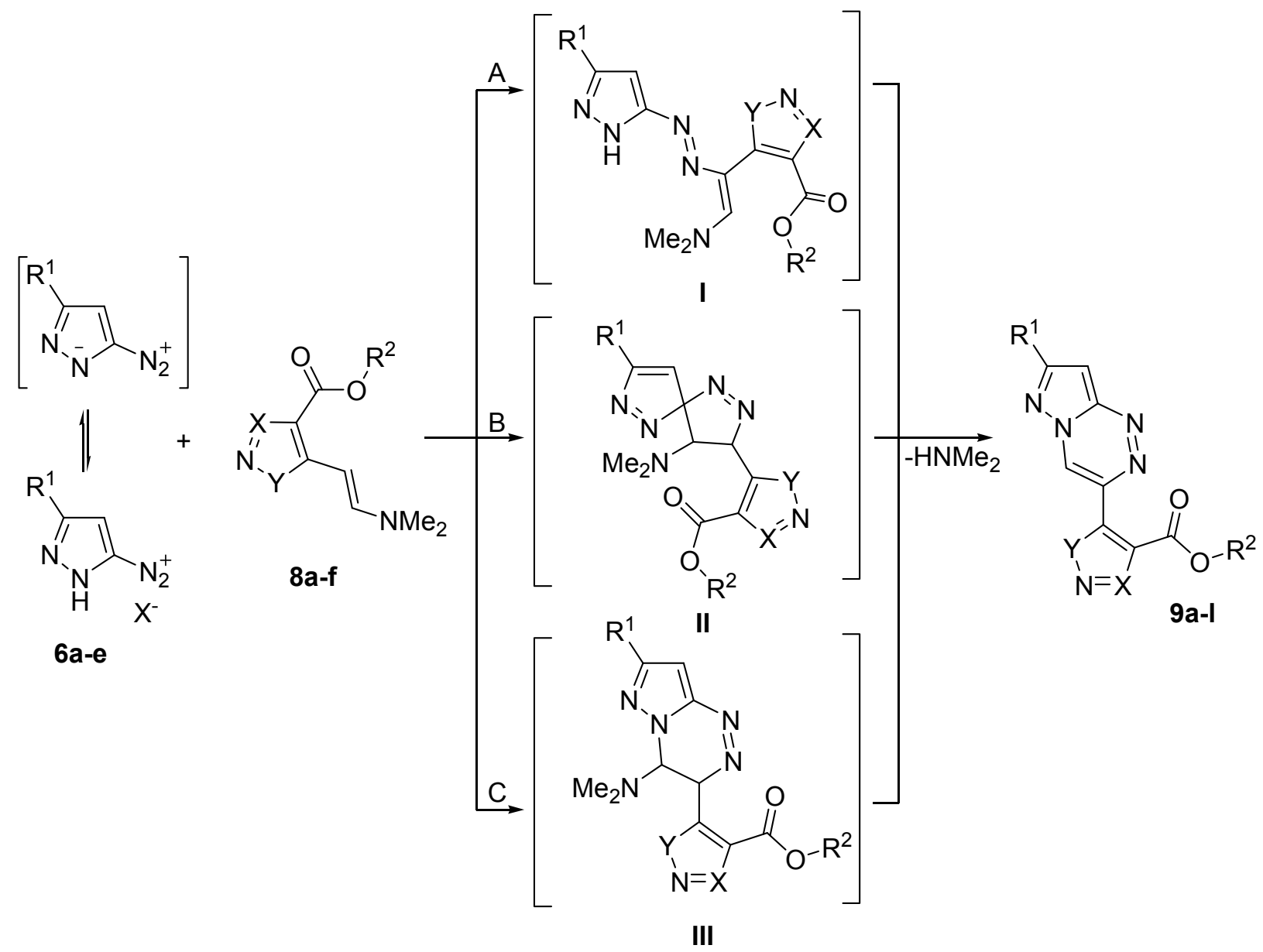

Scheme 5. Plausible mechanisms for the formation of 3-azolylpyrazolo[5,1-c][1,2,4]triazines 9a-l.

While triazine system formation in the two steps formally corresponds to the route $\mathbf{A}$, an alternate routes $\mathbf{B}, \mathbf{C}$ involving initial 1,3 union II followed by a [1,5]-sigmatropic shift and elimination of dimethyl amine or 1,7-cycloaddition of $\mathbf{6}$ to $\mathbf{8}$ to yield III, which then aromatizes to form the title compounds $\mathbf{9 a - 1}$ are also possible. ${ }^{10,12,13,15}$

We attempted to capture the intermediate I or II at a lower temperature (Scheme 5). However, it was difficult to check the presence of any intermediate product according to TLC. NMR experiments have shown that already $5 \mathrm{~min}$ after beginning of the reaction between cooled solutions of diazonium salt and enamine in dry DMSO- $d_{6}$ there were no longer signals of the starting compounds. Thus, unfortunately the trials to isolate either azo coupling intermediate or acyclic hydrazones failed.

The structures of the synthesized 3-azolylpyrazolo[5,1-c][1,2,4]triazines 9a-I were confirmed by IR, ${ }^{1} \mathrm{H},{ }^{13} \mathrm{C}$ NMR spectroscopy, mass spectrometry and elemental analysis.

In the IR spectra of 9a-l bands are observed corresponding to the asymmetric (1544$1638 \mathrm{~cm}^{-1}$ ) absorption modes of the $\mathrm{N}=\mathrm{N}$ bonds typical for a triazine structure. 
The mass spectra of the 3-azolylpyrazolo[5,1-c][1,2,4]triazines 9a-l show a molecular ion peak $\left(\mathrm{M}^{+}\right)$and decomposition under electron impact conditions with sequential cleavage of $\mathrm{CO}_{2} \mathrm{Et}$ or $\mathrm{CO}_{2} \mathrm{Me}$ thus pointing to the presence of ethoxy and methoxy carbonyl groups in the molecule, respectively. Ions with $m / z 143,177,173,157$ point to the presence of 3-arylpyrazole fragments in the molecules bearing isoxazolyl moiety 9f-1. For thiadiazolyl derivatives 9a-e the general fragmentation is not the same. The occurrence of 1,2,3-thiazole fragment is confirmed by the characteristic processes ${ }^{36}$ of loss of nitrogen molecule. Found together with the formation of the thiirene molecule there are also observed the pyrazole and pyrazolotriazine fragments with $m / z 69$ and 120, respectively.

The ${ }^{1} \mathrm{H}$ NMR spectra revealed the presence of the following signals: a singlet at $\delta_{\mathrm{H}}$ 9.91-10.13 due to the $\mathrm{H}-4$ proton of the triazine, a singlet at $\delta_{\mathrm{H}}$ 7.89-8.09 due to the $\mathrm{H}-8$ pyrazole proton and two multiplets in the region 7.04-8.18 due to the aromatic protons of pyrazole and triazine, respectively. The absence of a signal at $\delta_{\mathrm{H}} 12.00-13.00$ assigned to NH pyrazole proton, shows that this part of molecule has been involved in the reaction, and moreover the ${ }^{1} \mathrm{H}$ spectra are free of signals characteristic for the dimethylamine protons.

The ${ }^{13} \mathrm{C}$ NMR spectra revealed signals for all carbons of compounds 9a-l and most significantly there is a C-4 signal at $\delta_{\mathrm{C}}$ 95.22-96.84, proving triazine formation. The ${ }^{13} \mathrm{C}$ spectrum showed aromatic signals in the region $\delta_{\mathrm{C}} 121.24-134.10$ for both pyrazole and triazine aromatic carbons. At lower field one can see the signals due to the $\mathrm{C}=\mathrm{O}$ group of the ester function and to quaternary carbons. The DEPT spectrum allows assigning exactly the signal at $\delta_{\mathrm{C}}$ 124.12-124.84 as C-8 since it is connected with a proton.

In addition, in the comparison of the ${ }^{13} \mathrm{C}$ spectra of diazonium salts 6a-e and pyrazolo[5,1c] $[1,2,4]$ triazines 9a-l we have noticed that the spectra of the former compounds exhibit signals of the carbon attached to diazonium function in the region $\delta_{\mathrm{C}} 122.7-124.1$ according to $2 \mathrm{D}$ HMBC spectra. On the other hand, the signals of the quaternary carbons of the final compounds are at lower field $\left(\delta_{\mathrm{C}} 130.7-147.6\right)$. As for 3-R-pyrazole-5-diazonium salts this observation can be explained by the localization of the negative charge on the carbon of the pyrazole cycle.

Additional support for the structures of compounds 9a-l as pyrazolo[5,1-c][1,2,4]triazines was given by X-ray analysis of a single crystal of 9e which was successfully obtained by crystallization from tetrahydrofuran. The compound crystallizes into the monoclinic space group $\mathrm{P} 2{ }_{1} / \mathrm{n}$ (Fig. 1). Both rings are planar (rms deviations 0.001 and $0.002 \AA$ for thiadiazole and pyrazolo[5,1-c][1,2,4]triazine rings, respectively) and make a dihedral angle of $4.40(7)^{\circ}$. This almost planar conformation is stabilized by an intramolecular $\mathrm{C}-\mathrm{H} \cdots \mathrm{O}$ hydrogen bond [C6$\mathrm{H} 6 \cdots \mathrm{O} 2$ with $\mathrm{H} 6 \cdots \mathrm{O} 22.101(18) \AA]$. The molecules stack by $\pi$ - $\pi$ interactions into layers parallel to the plane (205). The shortest distance between these layers is between the centroids of neighboring thiadiazole and pyrazole rings [3.483(1) $\AA]$. 


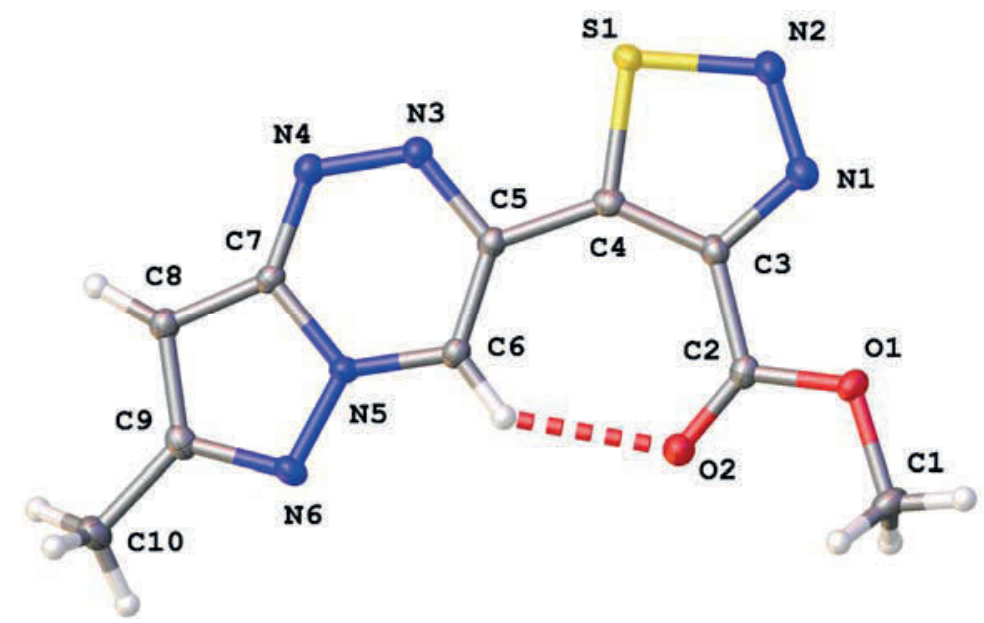

Figure 1. The molecular structure of 9e with displacement ellipsoids drawn at the $50 \%$ probability level and intramolecular hydrogen bond drawn as dashed line.

\section{Conclusions}

We have demonstrated a simple, regioselective and convenient method for the synthesis of novel 3 -substituted pyrazolo[5,1-c][1,2,4]triazines by reaction of pyrazole-5-diazonium salts with $\beta$ azolyl enamines. In this context, twelve new reported 3-azolylpyrazolo[5,1-c][1,2,4]triazines were isolated and characterized. The crystal data for a representative compound pointed out its planar structure and formation of the intramolecular hydrogen bonding which stabilizes the molecule. Plausible mechanisms for the formation of the title compounds were proposed. The study of scope and limitation of this reaction is in progress in our laboratories.

\section{Experimental Section}

General. Melting points were determined on a Stuart SMP30 and are uncorrected. The ${ }^{1} \mathrm{H}$ and ${ }^{13} \mathrm{C}$ NMR spectra were recorded on a Bruker Avance 400 spectrometer in DMSO- $d_{6}$ at 400 and $100 \mathrm{MHz}$, respectively. TMS was used as the internal standard. IR spectra were measured on a Bruker Alpha FT-IR spectrometer (ZnSe). The samples were examined directly as solids and $v_{\max }$ values were given for the main absorption bands. The results of elemental analysis for the obtained compounds correspond to calculated data (Perkin Elmer 2400 II). The reactions were monitored and the purity of the products was checked by TLC with Silufol UV-254 (silica gel STC-1A as the sorbent) using the following solvent systems: chloroform/ethanol, 5:1; hexane/ethyl acetate, 3:1.

The single-crystal X-ray diffraction data for 9e were collected on an Agilent SuperNova diffractometer with Eos CCD detector, $\mathrm{MoK}_{\alpha}$ radiation, $\lambda=0.71073 \AA$. Data frames were 
processed (unit cell determination, intensity data integration, correction for Lorentz and polarization effects, and empirical absorption correction) using CrysAlis PRO. ${ }^{37}$ The structure was solved by direct methods and refined by full-matrix least-squares based on $\mathrm{F}^{2}$ using the SHELX ${ }^{38}$ and Olex $2 .{ }^{39} \mathrm{H}$ atoms were found in difference density maps and refined freely with isotropic temperature factors.

The starting enamines: ethyl 8a and methyl 5-[(E)-2-(N,N-dimethylamino)ethenyl]-1,2,3thiadiazole-4-carboxylate $\mathbf{8 b},(E)$-methyl 8c and $(E)$-ethyl 5-[2-(N,N-dimethylamino)vinyl]-3phenylisoxazole-4-carboxylate 8d, $(E)$-methyl 3-(2-chloro-6-fluorophenyl)-5-[2-( $N, N$-dimethylamino)vinyl]isoxazole-4-carboxylate $\mathbf{8 e}$, (E)-ethyl 3-(3-fluorophenyl)-5-[2-(N,N-dimethylamino)vinyl]isoxazole-4-carboxylate 8 f were synthesized by known procedures. ${ }^{33,34}$

General procedure for the synthesis of 3-aryl-1H-pyrazole-5-diazonium hydrosulfates (6ad). A cooled solution of $\mathrm{NaNO}_{2}(0.08 \mathrm{~g}, 1.2 \mathrm{mmol})$ in water $(0.5 \mathrm{~mL})$ was added dropwise to a stirring suspension of 3-aryl-5-aminopyrazole 5a-d (1.0 mmol) in $30 \% \mathrm{H}_{2} \mathrm{SO}_{4}(4 \mathrm{~mL}, 2 \mathrm{mmol})$ at $0{ }^{\circ} \mathrm{C}$. The reaction mixture was stirred at this temperature for $30 \mathrm{~min}$. Then, the formed precipitate was collected by filtration, washed with cold water $(3 \mathrm{~mL})$ and dried in vacuo.

3-Phenyl-1H-pyrazole-5-diazonium hydrosulfate (6a). Pale beige solid, yield $0.22 \mathrm{~g}, 81 \%$, mp 129-130 ${ }^{\circ} \mathrm{C}$ (decomposition). ${ }^{1} \mathrm{H}$ NMR (400 MHz, DMSO- $\left.d_{6}\right): \delta_{\mathrm{H}} 8.10(\mathrm{~s}, 1 \mathrm{H}, \mathrm{H}-4), 7.90(\mathrm{~d}$, $\left.{ }^{3} J_{(\mathrm{HH})} 7.3 \mathrm{~Hz}, 2 \mathrm{H}, \mathrm{H}-2^{\prime}, 6^{\prime}\right), 7.61-7.55\left(\mathrm{~m}, 3 \mathrm{H}, \mathrm{H}-3^{\prime}, 4^{\prime}, 5^{\prime}\right) ;{ }^{13} \mathrm{C} \mathrm{NMR}\left(100 \mathrm{MHz}, \mathrm{DMSO}-d_{6}\right): \delta_{\mathrm{C}}$ 147.1 (C-3), 130.4 (C-1'), 129.5 (C-2',6'), 126.4 (C-3',5'), 126.8 (C-4'), 122.7 (C-5), 110.2 (C-4). FT-IR $\left(v_{\max } / \mathrm{cm}^{-1}\right): 3222(\mathrm{NH}), 2275\left(\mathrm{~N}_{2}{ }^{+}\right)$.

3-(p-Tolyl)-1H-pyrazole-5-diazonium hydrosulfate $(6 \mathrm{~b})$. Beige solid, yield $0.21 \mathrm{~g}, 73 \%$, mp 206-207 ${ }^{\circ} \mathrm{C}$ (decomposition). ${ }^{1} \mathrm{H}$ NMR (400 MHz, DMSO- $\left.d_{6}\right): \delta_{\mathrm{H}} 8.09(\mathrm{~s}, 1 \mathrm{H}, \mathrm{H}-4), 7.80(\mathrm{~d}$, $\left.{ }^{3} J_{(\mathrm{HH})} 8.0 \mathrm{~Hz}, 2 \mathrm{H}, \mathrm{H}-2^{\prime}, 6^{\prime}\right), 7.40\left(\mathrm{~d},{ }^{3} J_{(\mathrm{HH})} 8.0 \mathrm{~Hz}, 2 \mathrm{H}, \mathrm{H}-3^{\prime}, 5^{\prime}\right), 2.38\left(\mathrm{~s}, 3 \mathrm{H}, \mathrm{CH}_{3}\right) ;{ }^{13} \mathrm{C} \mathrm{NMR}$ $\left(100 \mathrm{MHz}, \mathrm{DMSO}-d_{6}\right): \delta_{\mathrm{C}} 146.7$ (C-3), 140.7 (C-1'), 130.1 (C-2',6'), $126.4\left(\mathrm{C}-3^{\prime}, 5^{\prime}\right), 123.8$ (C-5), $123.2(\mathrm{C}-4), 109.4(\mathrm{C}-4)$. FT-IR $\left(v_{\max } / \mathrm{cm}^{-1}\right): 3217(\mathrm{NH}), 2280\left(\mathrm{~N}_{2}{ }^{+}\right)$.

3-(p-Methoxyphenyl)-1H-pyrazole-5-diazonium hydrosulfate (6c). Beige solid, yield $0.20 \mathrm{~g}$, 67\%, mp 204-205 ${ }^{\circ} \mathrm{C}$ (decomposition). ${ }^{1} \mathrm{H}$ NMR (400 MHz, DMSO- $\left.d_{6}\right): \delta_{\mathrm{H}} 8.00$ (s, 1H, H-4), $7.87\left(\mathrm{~d},{ }^{3} J_{(\mathrm{HH})} 8.7 \mathrm{~Hz}, 2 \mathrm{H}, \mathrm{H}-2^{\prime}, 6^{\prime}\right), 7.12\left(\mathrm{~d},{ }^{3} J_{(\mathrm{HH})} 8.7 \mathrm{~Hz}, 2 \mathrm{H}, \mathrm{H}-3\right.$ ', 5'), 3.84 (s, 3H, OCH $)$; ${ }^{13} \mathrm{C}$ NMR $\left(100 \mathrm{MHz}, \mathrm{DMSO}-d_{6}\right): \delta_{\mathrm{C}} 161.2\left(\mathrm{C}-4{ }^{\prime}\right), 146.5(\mathrm{C}-3), 128.2\left(\mathrm{C}-2^{\prime}, 6^{\prime}\right), 124.1(\mathrm{C}-5)$, $118.2\left(\mathrm{C}-1^{\prime}\right), 115.1\left(\mathrm{C}-3^{\prime}, 5^{\prime}\right), 109.4(\mathrm{C}-4)$. FT-IR $\left(v_{\max } / \mathrm{cm}^{-1}\right): 3247(\mathrm{NH}), 2271\left(\mathrm{~N}_{2}{ }^{+}\right)$.

3-(p-Chlorophenyl)-1H-pyrazole-5(3)-diazonium hydrosulfate (6d). Beige solid, yield $0.25 \mathrm{~g}$, $84 \%, \mathrm{mp} 154-156{ }^{\circ} \mathrm{C}$ (decomposition). ${ }^{1} \mathrm{H}$ NMR (400 MHz, DMSO- $\left.d_{6}\right): \delta_{\mathrm{H}} 8.13$ (s, 1H, H-4), $7.91\left(\mathrm{~d},{ }^{3} J_{(\mathrm{HH})} 8.5 \mathrm{~Hz}, 2 \mathrm{H}, \mathrm{H}-2^{\prime}, 6^{\prime}\right), 7.65\left(\mathrm{~d},{ }^{3} J_{(\mathrm{HH})} 8.5 \mathrm{~Hz}, 2 \mathrm{H}, \mathrm{H}-3\right.$ ', 5'); ${ }^{13} \mathrm{C} \mathrm{NMR}(100 \mathrm{MHz}$, DMSO- $\left.d_{6}\right): \delta_{\mathrm{C}} 145.8(\mathrm{C}-3), 135.4\left(\mathrm{C}-1^{\prime}\right), 129.7\left(\mathrm{C}-3^{\prime}, 5^{\prime}\right), 128.4\left(\mathrm{C}-2^{\prime}, 6^{\prime}\right), 125.3\left(\mathrm{C}-4^{\prime}\right), 123.6(\mathrm{C}-$ 5), $110.7(\mathrm{C}-4)$. FT-IR $\left(v_{\max } / \mathrm{cm}^{-1}\right): 3199(\mathrm{NH}), 2275\left(\mathrm{~N}_{2}{ }^{+}\right)$.

General procedure for the reaction of 3-substituted pyrazole-5-diazonium salts (6a-d) with 3-azolyl enamines (8a-f). To a stirred solution of diazonium salt 6a-d (1 mmol) in $\mathrm{MeCN}$ $(2 \mathrm{~mL})$, a solution of enamine 8a-f $(1 \mathrm{mmol})$ in the same solvent $(2 \mathrm{~mL})$ was added at room temperature (see Table 1). The reaction mixture was stirring at this temperature for $0.7-4.5 \mathrm{~h}$ 
(see Table 1). After disappearing of the starting compounds as checked by TLC, the formed precipitate was filtered off. The gummy product was purified by washing with diethyl ether (5$10 \mathrm{~mL}$ ), then dried and recrystallized from a mixture of chloroform and acetonitrile.

3-(4'-Ethoxycarbonyl-1,2,3-thiadiazolyl)-7-phenylpyrazolo[5,1-c][1,2,4]triazine (9a). Yellow solid, yield $0.23 \mathrm{~g}, 65 \%$, mp $180-181{ }^{\circ} \mathrm{C}$. ${ }^{1} \mathrm{H}$ NMR (400 MHz, DMSO- $\left.d_{6}\right): \delta_{\mathrm{H}} 10.09(\mathrm{~s}, 1 \mathrm{H}, \mathrm{H}-$ 4), $8.21\left(\mathrm{~d},{ }^{3} J_{(\mathrm{HH})} 7.2 \mathrm{~Hz}, 2 \mathrm{H}, \mathrm{H}-2^{\prime \prime}, 6^{\prime \prime}\right), 8.16(\mathrm{~s}, 1 \mathrm{H}, \mathrm{H}-8), 7.61-7.54\left(\mathrm{~m}, 3 \mathrm{H}, \mathrm{H}-3^{\prime \prime}, 4^{\prime \prime}, 5^{\prime \prime}\right)$, $4.49\left(\mathrm{q},{ }^{2} J_{(\mathrm{HH})} 7.1 \mathrm{~Hz}, 2 \mathrm{H}, \quad \mathrm{OCH}_{2} \mathrm{CH}_{3}\right), 1.35\left(\mathrm{t},{ }^{2} J_{(\mathrm{HH})} 7.1 \mathrm{~Hz}, 3 \mathrm{H}, \quad \mathrm{OCH}_{2} \underline{\mathrm{CH}}_{3}\right) ;{ }^{13} \mathrm{C} \mathrm{NMR}$ $\left(100 \mathrm{MHz}, \mathrm{DMSO}-d_{6}\right): \delta_{\mathrm{C}} 159.1,157.4,146.4,140.0,139.5,139.2,125.4,125.0,124.41,121.2$, 95.7, 86.8, 86.5, 56.8, 10.4. FT-IR $\left(v_{\max } / \mathrm{cm}^{-1}\right)$ : $1708(\mathrm{C}=\mathrm{O}), 1569(\mathrm{~N}=\mathrm{N})$. Anal. Calcd. for $\mathrm{C}_{16} \mathrm{H}_{12} \mathrm{~N}_{6} \mathrm{O}_{2} \mathrm{~S}$ (352.38): C, 54.54; H, 3.43; N, 23.85\%. Found: C, 54.31; H, 3.46; N, 23.69\%.

3-(4'-Ethoxycarbonyl-1,2,3-thiadiazolyl)-7-(p-tolyl)pyrazolo[5,1-c][1,2,4]triazine

(9b).

Mustard solid, yield 0.26 g, 71\%, mp 194-195 ${ }^{\circ} \mathrm{C} .{ }^{1} \mathrm{H}$ NMR (400 MHz, DMSO- $\left.d_{6}\right): \delta_{\mathrm{H}} 10.08(\mathrm{~s}$, $1 \mathrm{H}, \mathrm{H}-4), 8.01$ (d, $\left.{ }^{3} J_{(\mathrm{HH})} 7.8 \mathrm{~Hz}, 2 \mathrm{H}, \mathrm{H}-3^{\prime \prime}, 5^{\prime \prime}\right), 7.89$ (s, 1H, H-8), 7.30 (d, ${ }^{3} J_{(\mathrm{HH})} 7.8 \mathrm{~Hz}, 2 \mathrm{H}, \mathrm{H}-$ $\left.2^{\prime \prime}, 6^{\prime \prime}\right), 4.54\left(\mathrm{q},{ }^{2} J_{(\mathrm{HH})} 7.0 \mathrm{~Hz}, 2 \mathrm{H}, \mathrm{OCH}_{2} \mathrm{CH}_{3}\right), 2.41\left(\mathrm{~s}, 3 \mathrm{H}, \mathrm{CH}_{3}\right), 1.46\left(\mathrm{t},{ }^{2} J_{(\mathrm{HH})} 7.0 \mathrm{~Hz}, 3 \mathrm{H}\right.$, $\left.\mathrm{OCH}_{2} \underline{\mathrm{CH}}_{3}\right) ;{ }^{13} \mathrm{C}$ NMR $\left(100 \mathrm{MHz}, \mathrm{DMSO}-d_{6}\right): \delta_{\mathrm{C}} 160.5,158.5,156.5,149.9,147.0,140.1,133.7$, 129.5, 127.7, 126.6, 124.5, 96.0, 62.0, 20.8, 13.8. FT-IR $\left(v_{\max } / \mathrm{cm}^{-1}\right): 1706(\mathrm{C}=\mathrm{O}), 1615(\mathrm{~N}=\mathrm{N})$. Anal. Calcd. for $\mathrm{C}_{17} \mathrm{H}_{14} \mathrm{~N}_{6} \mathrm{O}_{2} \mathrm{~S}$ (366.40): C, 55.73; H, 3.85; N, 22.94\%. Found: C, 55.58; H, 4.03; N, 22.81\%.

3-(4'-Ethoxycarbonyl-1,2,3-thiadiazolyl)-7-(p-methoxyphenyl)pyrazolo[5,1-c][1,2,4]triazine (9c). Mustard solid, yield $0.27 \mathrm{~g}, 70 \%, \mathrm{mp} 177-178{ }^{\circ} \mathrm{C} .{ }^{1} \mathrm{H}$ NMR (400 MHz, DMSO- $\left.d_{6}\right): \delta_{\mathrm{H}}$ 10.04 (s, 1H, H-4), 8.07 (d, $\left.{ }^{3} J_{(\mathrm{HH})} 7.4 \mathrm{~Hz}, 2 \mathrm{H}, \mathrm{H}-3^{\prime \prime}, 5^{\prime \prime}\right), 7.89$ (s,1H, H-8), 7.04 (d, ${ }^{3} J_{(\mathrm{HH})} 7.4 \mathrm{~Hz}$, $\left.2 \mathrm{H}, \mathrm{H}-2^{\prime \prime}, 6^{\prime \prime}\right), 4.52\left(\mathrm{q},{ }^{2} J_{(\mathrm{HH})} 7.0 \mathrm{~Hz}, 2 \mathrm{H}, \mathrm{OCH}_{2} \mathrm{CH}_{3}\right), 3.85\left(\mathrm{~s}, 3 \mathrm{H}, \mathrm{OCH}_{3}\right), 1.44\left(\mathrm{t},{ }^{2} J_{(\mathrm{HH})} 7.0 \mathrm{~Hz}\right.$, $\left.3 \mathrm{H}, \mathrm{OCH}_{2} \mathrm{CH}_{3}\right) ;{ }^{13} \mathrm{C} \mathrm{NMR}\left(100 \mathrm{MHz}, \mathrm{DMSO}-d_{6}\right): \delta_{\mathrm{C}} 160.9,160.3,158.4,156.2,149.9,147.0$, 133.4, 128.1, 124.2, 122.9, 114.4, 95.3, 61.9, 55.1, 13.6. FT-IR $\left(v_{\max } / \mathrm{cm}^{-1}\right): 1705(\mathrm{C}=\mathrm{O})$, $1607(\mathrm{~N}=\mathrm{N})$. Anal. Calcd. for $\mathrm{C}_{17} \mathrm{H}_{14} \mathrm{~N}_{6} \mathrm{O}_{3} \mathrm{~S}$ (382.40): C, 53.40; H, 3.69; N, 21.98\%. Found: C, $53.28 ; \mathrm{H}, 3.93 ; \mathrm{N}, 21.57 \%$.

\section{3-(4'-Ethoxycarbonyl-1,2,3-thiadiazolyl)-7-(p-chlorophenyl)pyrazolo[5,1-c][1,2,4]triazine}

(9d). Yellow solid, yield $0.26 \mathrm{~g}, 67 \%$, mp $245-246{ }^{\circ} \mathrm{C} .{ }^{1} \mathrm{H}$ NMR (400 MHz, DMSO- $\left.d_{6}\right): \delta_{\mathrm{H}}$ 10.07 (s, 1H, H-4), 8.17 (d, $\left.{ }^{3} J_{(\mathrm{HH})} 8.0 \mathrm{~Hz}, 2 \mathrm{H}, \mathrm{H}-3^{\prime \prime}, 5^{\prime \prime}\right), 8.08$ (s, 1H, H-8), 7.77 (d, ${ }^{3} J_{(\mathrm{HH})} 8.0 \mathrm{~Hz}$, $\left.2 \mathrm{H}, \mathrm{H}-2^{\prime \prime}, 6^{\prime \prime}\right), 4.51\left(\mathrm{q},{ }^{2} J_{(\mathrm{HH})} 7.0 \mathrm{~Hz}, 2 \mathrm{H}, \mathrm{OCH}_{2} \mathrm{CH}_{3}\right), 1.41\left(\mathrm{t},{ }^{2} J_{(\mathrm{HH})} 7.0 \mathrm{~Hz}, 3 \mathrm{H}, \mathrm{OCH}_{2} \underline{\mathrm{CH}}_{3}\right)$; ${ }^{13} \mathrm{C}$ NMR $\left(100 \mathrm{MHz}, \mathrm{DMSO}-d_{6}\right): \delta_{\mathrm{C}} 160.5,157.3,156.4,150.2,147.6,135.2,134.1,129.6$, 129.3, 128.6, 125.1, 96,8, 62.2, 13.9. FT-IR $\left(v_{\max } / \mathrm{cm}^{-1}\right): 1717(\mathrm{C}=\mathrm{O}), 1601(\mathrm{~N}=\mathrm{N}), 788(\mathrm{C}-\mathrm{Cl})$. Anal. Calcd. for $\mathrm{C}_{16} \mathrm{H}_{11} \mathrm{ClN}_{6} \mathrm{O}_{2} \mathrm{~S}$ (386.82): C, 49.68; H, 2.87; N, 21.53\%. Found: C, 50.01; H, $3.12 ; \mathrm{N}, 21.53 \%$.

3-(4'-Methoxycarbonyl-1,2,3-thiadiazolyl)-7-methylpyrazolo[5,1-c][1,2,4]triazine

(9e).

A cooled solution of $\mathrm{NaNO}_{2}(0.08 \mathrm{~g}, 1.2 \mathrm{mmol})$ in water $(0.5 \mathrm{~mL})$ was added dropwise to a stirring suspension of 3-methyl-5-aminopyrazole 5 e $(0.097 \mathrm{~g}, 1.0 \mathrm{mmol})$ in $50 \% \mathrm{HBF}_{4}(2 \mathrm{~mL})$ at $0{ }^{\circ} \mathrm{C}$. The reaction mixture was stirred at this temperature until the disappearing of the starting amine. Then to the stirred diazo solution of 3-methyl-1H-pyrazole-5-diazonium tetrafluoroborate $\mathbf{6 e}$ in $\mathrm{HBF}_{4}$ a solution of enamine $\mathbf{8 b}(2 \mathrm{mmol})$ in $\mathrm{MeCN}(1 \mathrm{~mL})$ and $20 \%$ aqueous solution of 
$\mathrm{Na}_{2} \mathrm{CO}_{3}(5 \mathrm{~mL})$ were added at room temperature. The reaction mixture was stirring at this temperature for 1,2 h. After disappearing of the starting compounds checked by TLC the formed precipitate was filtered off. The crude product was recrystallized from a mixture of ethanol and acetonitrile. Yellow solid, yield $0.20 \mathrm{~g}, 73 \%$, mp $244-245{ }^{\circ} \mathrm{C} .{ }^{1} \mathrm{H}$ NMR (400 MHz, DMSO- $d_{6}$ ): $\delta_{\mathrm{H}} 9.98(\mathrm{~s}, 1 \mathrm{H}, \mathrm{H}-4), 7.41(\mathrm{~s}, 1 \mathrm{H}, \mathrm{H}-8), 4.00\left(\mathrm{~s}, 3 \mathrm{H}, \mathrm{OCH}_{3}\right), 2.60\left(\mathrm{~s}, 3 \mathrm{H}, \mathrm{CH}_{3}\right) ;{ }^{13} \mathrm{C} \mathrm{NMR}$ $\left(100 \mathrm{MHz}, \mathrm{DMSO}-d_{6}\right): \delta_{\mathrm{C}} 160.8,158.6,156.4,149.3,146.9,133.0,124.3,98.8,52.7,14.0$. FTIR $\left(v_{\max } / \mathrm{cm}^{-1}\right): 1716(\mathrm{C}=\mathrm{O}), 1574(\mathrm{~N}=\mathrm{N})$. Anal. Calcd. for $\mathrm{C}_{10} \mathrm{H}_{8} \mathrm{~N}_{6} \mathrm{O}_{2} \mathrm{~S}$ (276.28): C, 43.47; $\mathrm{H}$, 2.92; N, 30.42\%. Found: C, 43.72; H, 2.85; N, 30.32\%.

\section{3-(3'-Phenyl-4'-methoxycarbonylisoxazolyl)-7-phenylpyrazolo[5,1-c] $[1,2,4]$ triazine}

(9f).

Yellow solid, yield $0.25 \mathrm{~g}, 64 \%$, mp $232-233{ }^{\circ} \mathrm{C}$. ${ }^{1} \mathrm{H}$ NMR $\left(400 \mathrm{MHz}, \mathrm{DMSO}-d_{6}\right): \delta_{\mathrm{H}} 9.88(\mathrm{~s}$, $1 \mathrm{H}, \mathrm{H}-4), 8.16$ (d, $\left.{ }^{3} J_{(\mathrm{HH})} 7.0 \mathrm{~Hz}, 2 \mathrm{H}, \mathrm{H}-2^{\prime \prime}, 6^{\prime \prime}\right), 7.98$ (s, 1H, H-8), 7.73 (d, ${ }^{3} J_{(\mathrm{HH})} 5.5 \mathrm{~Hz}, 2 \mathrm{H}, \mathrm{H}-$ $\left.2^{\prime \prime \prime}, 6^{\prime \prime \prime}\right), 7.49-7.54\left(\mathrm{~m}, 6 \mathrm{H}, \mathrm{H}-3^{\prime \prime}, 4^{\prime \prime}, 5^{\prime \prime}, 3^{\prime \prime \prime}, 4^{\prime \prime \prime}, 5^{\prime \prime \prime}\right), 3.79\left(\mathrm{~s}, 3 \mathrm{H}, \mathrm{OCH}_{3}\right) ;{ }^{13} \mathrm{C} \mathrm{NMR}(100 \mathrm{MHz}$, DMSO- $\left.d_{6}\right): \delta_{\mathrm{C}} 166.1,161.7,161.7,158.4,150.4,132.4,130.7,130.3,130.2,129.0,128.6,128.4$, 127.8, 127.1, 126.8, 124.8, 96.4, 52.4. FT-IR $\left(v_{\max } / \mathrm{cm}^{-1}\right): 1733(\mathrm{C}=\mathrm{O}), 1631(\mathrm{~N}=\mathrm{N})$. Anal. Calcd. for $\mathrm{C}_{22} \mathrm{H}_{15} \mathrm{~N}_{5} \mathrm{O}_{3}$ (397.40): C, 66.49; H, 3.80; N, 17.62\%. Found: C, 66.85; H, 3.86; N, 17.73\%.

\section{3-(3'-Phenyl-4'-ethoxycarbonylisoxazolyl)-7-(p-tolyl)pyrazolo[5,1-c][1,2,4]triazine}

$(9 \mathrm{~g})$.

Yellow solid, yield $0.30 \mathrm{~g}, 70 \%$, mp $242-243{ }^{\circ} \mathrm{C} .{ }^{1} \mathrm{H}$ NMR $\left(400 \mathrm{MHz}, \mathrm{DMSO}-d_{6}\right): \delta_{\mathrm{H}}$ 9.87 (s,1H, H-4), 8.05 (d, $\left.{ }^{3} J_{(\mathrm{HH})} 7.7 \mathrm{~Hz}, 2 \mathrm{H}, \mathrm{H}-3^{\prime \prime}, 5^{\prime \prime}\right), 7.93$ (s, 1H, H-8), 7.73 (d, ${ }^{3} J_{(\mathrm{HH})} 6.6 \mathrm{~Hz}$, $\left.2 \mathrm{H}, \mathrm{H}-2^{\prime \prime \prime}, 6^{\prime \prime \prime}\right), 7.50-7.60\left(\mathrm{~m}, 3 \mathrm{H}, \mathrm{H}-3^{\prime}, 4^{\prime}, 5^{\prime}\right), 7.34\left(\mathrm{~d},{ }^{3} J_{(\mathrm{HH})} 7.7 \mathrm{~Hz}, 2 \mathrm{H}, 2^{\prime \prime}, 6^{\prime \prime}-\mathrm{H}\right), 4.26(\mathrm{q}$, $\left.{ }^{2} J_{(\mathrm{HH})} 7.0 \mathrm{~Hz}, 2 \mathrm{H}, \quad \mathrm{OCH}_{2} \mathrm{CH}_{3}\right), 3.08\left(\mathrm{~s}, 3 \mathrm{H}, \mathrm{CH}_{3}\right), 1.15\left(\mathrm{t},{ }^{2} J_{(\mathrm{HH})} 7.0 \mathrm{~Hz}, 3 \mathrm{H}, \mathrm{OCH}_{2} \underline{\mathrm{CH}}_{3}\right)$; ${ }^{13} \mathrm{C}$ NMR $\left(100 \mathrm{MHz}\right.$, DMSO- $\left.d_{6}\right): \delta_{\mathrm{C}} 166.1,161.8,161.0,158.4,150.4,140.1,132.2,130.3$, 129.6, 128.5, 128.5, 127.9, 127.2, 126.7, 124.8, 115.0, 96.0, 61.3, 20.9, 13.3. FT-IR $\left(v_{\max } / \mathrm{cm}^{-1}\right)$ : $1731(\mathrm{C}=\mathrm{O}), 1636(\mathrm{~N}=\mathrm{N})$. Anal. Calcd. for $\mathrm{C}_{24} \mathrm{H}_{19} \mathrm{~N}_{5} \mathrm{O}_{3}(425.45)$ : C, 67.76; H, 4.50; N, 16.46\%. Found: C, 67.32; H, 4.69; N, 16.08\%.

\section{3-(3'-Phenyl-4'-ethoxycarbonylisoxazolyl)-7-(p-methoxyphenyl)pyrazolo-[5,1-}

c] $[1,2,4]$ triazine (9h). Mustard solid, yield $0.25 \mathrm{~g}, 57 \%, \mathrm{mp} 230-231{ }^{\circ} \mathrm{C} .{ }^{1} \mathrm{H} \mathrm{NMR}(400 \mathrm{MHz}$, DMSO-d $\left.)_{6}\right): \delta_{\mathrm{H}} 9.81(\mathrm{~s}, 1 \mathrm{H}, \mathrm{H}-4), 8.11\left(\mathrm{~d},{ }^{3} J_{(\mathrm{HH})} 8.05 \mathrm{~Hz}, 2 \mathrm{H}, \mathrm{H}-3^{\prime \prime}, 5^{\prime \prime}\right), 7.94$ (s, 1H, H-8), $7.73\left(\mathrm{~d},{ }^{3} J_{(\mathrm{HH})} 5.0 \mathrm{~Hz}, 2 \mathrm{H}, \mathrm{H}-2^{\prime \prime \prime}, 6^{\prime \prime \prime}\right), 7.56-7.51\left(\mathrm{~m}, 3 \mathrm{H}, \mathrm{H}-3^{\prime \prime \prime}, 4^{\prime \prime \prime}, 5^{\prime \prime \prime}\right), 7.12\left(\mathrm{~d},{ }^{3} J_{(\mathrm{HH})} 8.05 \mathrm{~Hz}\right.$, $\left.2 \mathrm{H}, \mathrm{H}-2^{\prime \prime}, 6^{\prime \prime}\right), 4.24\left(\mathrm{q},{ }^{2} J_{(\mathrm{HH})} 7.0 \mathrm{~Hz}, 2 \mathrm{H}, \mathrm{OCH}_{2} \mathrm{CH}_{3}\right), 3.86\left(\mathrm{~s}, 3 \mathrm{H}, \mathrm{OCH}_{3}\right), 1.10\left(\mathrm{t},{ }^{2} J_{(\mathrm{HH})} 7.0 \mathrm{~Hz}\right.$, $\left.3 \mathrm{H}, \mathrm{OCH}_{2} \underline{\mathrm{CH}}_{3}\right) ;{ }^{13} \mathrm{C} \mathrm{NMR}\left(100 \mathrm{MHz}, \mathrm{DMSO}-d_{6}\right): \delta_{\mathrm{C}} 166.0,160.9,160.8,158.3,150.2,132.0$, 130.0, 128.4, 128.3, 128.2, 128.2, 127.1, 126.6, 124.4, 123.0, 114.4, 95.3, 61.1, 55.1, 13.1. FT-IR $\left(v_{\max } / \mathrm{cm}^{-1}\right): 1728(\mathrm{C}=\mathrm{O}), 1631(\mathrm{~N}=\mathrm{N})$.Anal. Calcd. for $\mathrm{C}_{24} \mathrm{H}_{19} \mathrm{~N}_{5} \mathrm{O}_{4}(441.45): \mathrm{C}, 65.30 ; \mathrm{H}, 4.34$; $\mathrm{N}, 15.86 \%$. Found: C, 65.37; H, 4.41; N, 15.95\%.

\section{3-(3'-Phenyl-4'-methoxycarbonylisoxazolyl)-7-(p-chlorophenyl)pyrazolo-[5,1-}

c] $[1,2,4]$ triazine (9i). Yellow solid, yield $0.41 \mathrm{~g}, 96 \%, \mathrm{mp} 257-258{ }^{\circ} \mathrm{C} .{ }^{1} \mathrm{H} \mathrm{NMR}(400 \mathrm{MHz}$, DMSO- $\left.d_{6}\right): \delta_{\mathrm{H}} 9.94$ (s, $\left.1 \mathrm{H}, \mathrm{H}-4\right), 8.20\left(\mathrm{~d},{ }^{3} J_{(\mathrm{HH})} 8.0 \mathrm{~Hz}, 2 \mathrm{H}, \mathrm{H}-3^{\prime \prime}, 5^{\prime \prime}\right), 8.13$ (s, 1H, H-8), 7.72 (d, $\left.{ }^{3} J_{(\mathrm{HH})} 8.0 \mathrm{~Hz}, 2 \mathrm{H}, \mathrm{H}-2^{\prime \prime}, 6^{\prime \prime}\right), 7.64-7.58\left(\mathrm{~m}, 5 \mathrm{H}, \mathrm{H}-2^{\prime \prime \prime}, 3^{\prime \prime \prime}, 4^{\prime \prime \prime}, 5^{\prime \prime \prime}, 6^{\prime \prime \prime}\right), 3.75\left(\mathrm{~s}, 3 \mathrm{H}, \mathrm{OCH}_{3}\right)$; ${ }^{13} \mathrm{C}$ NMR. (100 MHz, DMSO- $\left.d_{6}\right): \delta_{\mathrm{C}} 165.9,161.6,161.5,157.0,150.3,134.9,132.4,130.2$, $129.5,129.0,128.6,128.5,128.4,128.2,127.0,124.7,99.2,96.5,52.2$. FT-IR $\left(v_{\max } / \mathrm{cm}^{-1}\right)$ : 
$1729(\mathrm{C}=\mathrm{O}), 1638(\mathrm{~N}=\mathrm{N}), 808(\mathrm{C}-\mathrm{Cl})$. Anal. Calcd. for $\mathrm{C}_{23} \mathrm{H}_{16} \mathrm{ClN}_{5} \mathrm{O}_{3}$ (431.84): C, 61.19; H, 3.27; N, 16.22\%. Found: C, 59.78; H, 3.01; N, 15.96\%.

3-[3'-(2'"'-Chloro-6'"'-fluorophenyl)-4'-methoxycarbonylisoxazolyl]-7-(p-methylphenyl)pyrazolo[5,1-c][1,2,4]triazine (9j). Yellow solid, yield $0.34 \mathrm{~g}, 73 \%, 198-200{ }^{\circ} \mathrm{C}$. ${ }^{1} \mathrm{H} \mathrm{NMR}$ $\left(400 \mathrm{MHz}, \mathrm{DMSO}-d_{6}\right): \delta_{\mathrm{H}} 9.98(\mathrm{~s}, 1 \mathrm{H}, \mathrm{H}-4), 8.05$ (d, $\left.{ }^{3} J_{(\mathrm{HH})} 8.0 \mathrm{~Hz}, 2 \mathrm{H}, \mathrm{H}-3^{\prime \prime}, 5^{\prime \prime}\right), 7.91$ (s, 1H, H8), $7.63\left(\mathrm{dd},{ }^{2} J_{(\mathrm{HH})} 8.3 \mathrm{~Hz},{ }^{3} J_{(\mathrm{HH})} 4.6 \mathrm{~Hz}, 1 \mathrm{H}, \mathrm{H}-5^{\prime \prime \prime}\right), 7.47$ (d, $\left.{ }^{3} J_{(\mathrm{HH})} 8.1 \mathrm{~Hz}, 1 \mathrm{H}, \mathrm{H}-3^{\prime \prime \prime}\right), 7.35$ (dd, $\left.{ }^{2} J_{(\mathrm{HH})} 8.3 \mathrm{~Hz},{ }^{3} J_{(\mathrm{HH})} 8.1 \mathrm{~Hz}, 1 \mathrm{H}, \mathrm{H}-4^{\prime \prime \prime}\right), 7.33\left(\mathrm{~d},{ }^{3} J_{(\mathrm{HH})} 8.0 \mathrm{~Hz}, 2 \mathrm{H}, \mathrm{H}-2^{\prime \prime}, 6^{\prime \prime}\right), 3.68\left(\mathrm{~s}, 3 \mathrm{H}, \mathrm{OCH}_{3}\right)$, $2.44\left(\mathrm{~s}, 3 \mathrm{H}, \mathrm{CH}_{3}\right) ;{ }^{13} \mathrm{C}$ NMR $\left(100 \mathrm{MHz}, \mathrm{DMSO}-d_{6}\right): \delta_{\mathrm{C}} 166.6,160.4,159.3,157.7,154.9,149.5$, 139.3, 132.8, 132.3, 130.9, 128.8, 127.0, 125.9, 125.4, 124.8, 114.8, 113.8, 110.0, 95.2, 51.4, 20.0. FT-IR $\left(v_{\max } / \mathrm{cm}^{-1}\right): 1720(\mathrm{C}=\mathrm{O}), 1587(\mathrm{~N}=\mathrm{N}), 1440(\mathrm{C}-\mathrm{F}), 833(\mathrm{C}-\mathrm{Cl}), 785(\mathrm{C}-\mathrm{Cl})$. Anal. Calcd. for $\mathrm{C}_{23} \mathrm{H}_{15} \mathrm{ClFN}_{5} \mathrm{O}_{3}$ (463.86): C, 59.56; H, 3.26; N, 15.10\%. Found: C, 59.13; H, 3.09; N, $15.05 \%$.

\section{3-[3'-(2'"'-Chloro-6"''-fluorophenyl)-4'-methoxycarbonylisoxazolyl]-7-(p-chlorophenyl)-} pyrazolo[5,1-c][1,2,4]triazine (9k). Orange solid, yield $0.31 \mathrm{~g}, 64 \%, \mathrm{mp} 221-222{ }^{\circ} \mathrm{C} .{ }^{1} \mathrm{H}$ NMR $\left(400 \mathrm{MHz}, \mathrm{DMSO}-d_{6}\right): \delta_{\mathrm{H}} 10.05(\mathrm{~s}, 1 \mathrm{H}, \mathrm{H}-4), 8.20\left(\mathrm{~d},{ }^{3} J_{(\mathrm{HH})} 8.0 \mathrm{~Hz}, 2 \mathrm{H}, \mathrm{H}-3^{\prime \prime}, 5^{\prime \prime}\right), 8.08(\mathrm{~s}, 1 \mathrm{H}$, $\mathrm{H}-8), 7.65\left(\mathrm{dd},{ }^{2} J_{(\mathrm{HH})} 8.0 \mathrm{~Hz},{ }^{3} J_{(\mathrm{HH})} 6.5 \mathrm{~Hz}, 1 \mathrm{H}, \mathrm{H}-5^{\prime \prime \prime}\right), 7.55$ (d, $\left.{ }^{3} J_{(\mathrm{HH})} 8.0 \mathrm{~Hz}, 2 \mathrm{H}, \mathrm{H}-2^{\prime \prime}, 6^{\prime \prime}\right)$, $7.49\left(\mathrm{~d},{ }^{3} J_{(\mathrm{HH})} 8.5 \mathrm{~Hz}, 1 \mathrm{H}, \mathrm{H}-3^{\prime \prime \prime}\right), 7.37$ (dd, $\left.{ }^{2} J_{(\mathrm{HH})} 8.5 \mathrm{~Hz},{ }^{3} J_{(\mathrm{HH})} 8.0 \mathrm{~Hz}, 1 \mathrm{H}, \mathrm{H}-4^{\prime \prime \prime}\right), 3.68$ (s, 3H, $\left.\mathrm{OCH}_{3}\right) ;{ }^{13} \mathrm{C} \mathrm{NMR}\left(100 \mathrm{MHz}, \mathrm{DMSO}-d_{6}\right): \delta_{\mathrm{C}} 166.2,160.5,158.7,157.0,155.8,150.5,138.2$, $131.3,130.3,128.7,127.0,126.7,125.4,124.7,123.8,111.9,110.0,96.8,95.4,50.7$. FT-IR $\left(v_{\max } / \mathrm{cm}^{-1}\right): 1722(\mathrm{C}=\mathrm{O}), 1544(\mathrm{~N}=\mathrm{N}), 1448(\mathrm{C}-\mathrm{F}), 836(\mathrm{C}-\mathrm{Cl}), 783(\mathrm{C}-\mathrm{Cl})$. Anal. Calcd. for $\mathrm{C}_{22} \mathrm{H}_{12} \mathrm{Cl}_{2} \mathrm{FN}_{5} \mathrm{O}_{3}$ (484.28): C, 54.56; H, 2.50; N, 14.46\%. Found: C, 54.43; H, 2.60; N, 14.11\%.

3-[3'-(m-Fluorophenyl)-4'-ethoxycarbonylisoxazolyl]-7-phenylpyrazolo[5,1-c] [1,2,4]triazine (9l). Yellow solid, yield $0.22 \mathrm{~g}, 52 \%, \mathrm{mp} 195-196{ }^{\circ} \mathrm{C}$. ${ }^{1} \mathrm{H}$ NMR (400 MHz, DMSO- $\left.d_{6}\right): \delta_{\mathrm{H}}$ $10.00(\mathrm{~s}, 1 \mathrm{H}, \mathrm{H}-4), 8.22-8.16\left(\mathrm{~m}, 3 \mathrm{H}, 2 \mathrm{H}_{\mathrm{Ar}}, \mathrm{H}-8\right), 7.65-7.45\left(\mathrm{~m}, 7 \mathrm{H}, 7 \mathrm{H}_{\mathrm{Ar}}\right), 4.24\left(\mathrm{q},{ }^{2} J_{(\mathrm{HH})}\right.$ $\left.6.9 \mathrm{~Hz}, 2 \mathrm{H}, \underline{\mathrm{OCH}}_{2} \mathrm{CH}_{3}\right), 1.09\left(\mathrm{t},{ }^{2} J_{(\mathrm{HH})} 6.9 \mathrm{~Hz}, 3 \mathrm{H}, \mathrm{OCH}_{2} \underline{\mathrm{CH}}_{3}\right) ;{ }^{13} \mathrm{C} \mathrm{NMR}\left(100 \mathrm{MHz}, \mathrm{DMSO}-d_{6}\right)$ : $\delta_{\mathrm{C}} 166.8,161.1,160.8,160.6,158.4,150.5,132.3,130.9,130.8,130.4,129.2,126.9,125.5$, 125.0, 115.9, 115.7, 110.5, 99.5, 96.5, 61.5, 13.4. FT-IR $\left(v_{\max } / \mathrm{cm}^{-1}\right): 1723(\mathrm{C}=\mathrm{O}), 1631(\mathrm{~N}=\mathrm{N})$, 1459 (C-F). Anal. Calcd. for $\mathrm{C}_{23} \mathrm{H}_{16} \mathrm{FN}_{5} \mathrm{O}_{3}$ (429.41): C, 64.33; H, 3.76; N, 16.31\%. Found: C, 63.98; H, 3.55; N, 16.43\%.

Crystal Data for 9e. $(M=276.28 \mathrm{~g} / \mathrm{mol})$, monoclinic, space group $\mathrm{P} 2{ }_{1} / \mathrm{n}$ (no. 14), $a=$ 5.73223(14) $\AA, b=16.3235(4) \AA, c=12.0595(3) \AA, \beta=91.991(2)^{\circ}, V=1127.73(5) \AA^{3}, Z=$ $4, T=100.01(10) \mathrm{K}, \mu(\mathrm{MoK} \alpha)=0.296 \mathrm{~mm}^{-1}$, Dcalc $=1.627 \mathrm{~g} / \mathrm{cm}^{3}, 4626$ reflections measured $\left(5^{\circ} \leq 2 \Theta \leq 52.74^{\circ}\right), 2302$ unique $\left(R_{\text {int }}=0.0189, R_{\text {sigma }}=0.0308\right)$ which were used in all calculations. The final $R_{1}$ was $0.0349(>2 \operatorname{sigma}(\mathrm{I}))$ and $w R_{2}$ was 0.0865 (all data).

Single crystal data for compound 9e (CCDC 1437673) has been deposited in the Cambridge Crystallographic Data Center and it can be obtained free of charge via http://www.ccdc.cam.ac.uk/conts/retrieving.html (or from the CCDC, 12 Union Road, Cambridge CB2 1EZ, UK; fax: +44 1223 336033; e-mail: deposit@ccdc.cam.ac.uk). 


\section{Acknowledgements}

The Russian authors thank the Ministry of Education and Science of the Russian Federation (State task 4.1626.2014/K) and Russian Foundation for Basic Research (grant № 14-03-01033) for financial support. The authors from Belgium thank the Hercules Foundation for supporting the purchase of equipment through the project AKUL/09/0035, Molybdenum high-energy X-ray source for in-situ diffraction studies of advanced materials and single crystals.

\section{References}

1. Sadchikova, E. V.; Mokrushin, V. S. Russ. Chem. Bull. 2005, 54, 354. http://dx.doi.org/10.1007/s11172-005-0259-7

2. Bezmaternykh, M. A.; Mokrushin, V. S.; Sadchikova, E. V. Chem. Heterocycl. Compd. 2000, 36, 465 . http://dx.doi.org/10.1007/BF02269547

3. Shchegol'kov, E. V.; Burgart, Ya. V.; Khudina, O. G.; Saloutin, V. I.; Chupakhin, O. N. Russ. Chem. Rev. 2010, 79, 31. http://dx.doi.org/10.1070/RC2010v079n01ABEH004048

4. Shchegol'kov, E. V.; Sadchikova, E. V.; Burgart, Ya. V.; Saloutin, V. I. Russ. Chem. Bull. 2008, $57,612$.

http://dx.doi.org/10.1007/s11172-008-0096-6

5. Rusinov, V. L.; Ulomskii, E. N.; Chupakhin, O. N.; Charushin, V. N. Russ. Chem. Bull. 2008, $57,985$.

http://dx.doi.org/10.1007/s11172-008-0130-8

6. Bezmaternykh, M. A.; Mokrushin, V. S.; Pospelova, T. A., Eltsov, O. S. Chem. Heterocycl. Compd. 1998, 34, 702. http://dx.doi.org/10.1007/BF02252280

7. Dürr, H.; Schmitz, H. Chem. Ber. 1978, 111, 2258. http://dx.doi.org/10.1002/cber.19781110620

8. Elnagdi, M. H.; Elmoghayar, M. R. H.; Kandeel, E. M.; Ibrahim, M. K. A. J. Heterocycl. Chem. 1977, 14, 227. http://dx.doi.org/10.1002/jhet.5570140212

9. Padwa, A.; Woolhouse, A. D.; Blount, J. J. J. Org. Chem. 1983, 48, 1069. http://dx.doi.org/10.1021/jo00155a028

10. Magee, W. L.; Rao, C. B.; Glinka, J.; Hui, H.; Amick, T. J.; Fiscus, D.; Kakodkar, S.; Nair, M.; Shechter, H. J. Org. Chem. 1987, 52, 5538.

http://dx.doi.org/10.1021/jo00234a008

11. Elnagdi, M. H.; Elmoghayar, M. R. H.; Fahmy, S. M.; Ibrahim, M. K. A.; Alnima, H. H. Z. Naturforsch., B: Chem. Sci. 1978, 33b, 216. 
http://dx.doi.org/10.1515/znb-1978-0220

12. Padwa, A.; Kumagai, T.; Woolhouse, A. D. J. Org. Chem. 1983, 48, 2330. http://dx.doi.org/10.1021/jo00162a007

13. Padwa, A.; Kumagai, T. Tetrahedron Lett. 1981, 22, 1199. http://dx.doi.org/10.1016/S0040-4039(01)90273-4

14. Kočevar, M.; Stanovnik, B.; Tišler, M. Heterocycles 1977, 6, 681. http://dx.doi.org/10.3987/R-1977-06-0681

15. Ghozlan, S. S.; Abdelhamid, I. A.; Gaber, H.; Elnagdi, M. H. J. Chem. Res. 2004, 12, 789. http://dx.doi.org/10.3184/0308234043431230

16. Ege, G.; Gilbert, K.; Franz, H. Synthesis 1977, 556. http://dx.doi.org/10.1055/s-1977-24471

17. Stevens, M. F. G.; Hickman, J. A.; Stone, R.; Gibson, N. W.; Baig, G. U.; Lunt, E.; Newton, C. G. J. Med. Chem. 1984, 27, 196.

http://dx.doi.org/10.1021/jm00368a016

18. Ege, G.; Gilbert, K.; Heck, R. Chem. Ber. 1984, 117, 1726. http://dx.doi.org/10.1002/cber.19841170508

19. Cheng, C. C.; Elslager, E. F.; Werbel, L. M.; Priebe, S. R.; Leopold, W. R. J. Med. Chem. 1986, 29, 1544.

http://dx.doi.org/10.1021/jm00158a041

20. Lunt, E.; Newton, C. G.; Smith, C.; Stevens, G. P.; Stevens, M. F. G.; Straw, C. G.; Walsh, R. J. A.; Warren, P. J.; Fizames, C.; Lavelle, F.; Langdon, S. P.; Vickers, L. M. J. Med. Chem. 1987, 30, 357.

http://dx.doi.org/10.1021/jm00385a018

21. Wang, Y.; Stevens, M. F. G.; Chan, T.-M.; DiBenedetto, D.; Ding, Z-X.; Gala, D.; Hou, D.; Kugelman, M.; Leong, W.; Kuo, S-C.; Mas, J. L.; Schumacher, D. P.; Schutts, B. P.; Smith, L.; Zhan, Z-Y.J. J. Org. Chem. 1997, 62, 7288. http://dx.doi.org/10.1021/j09708021

22. Wu, Y.-C.; Zou, X.-M.; Hu, F.-Z.; Yang, H.-Z. J. Heterocycl. Chem. 2005, 42, 609. http://dx.doi.org/10.1002/jhet.5570420421

23. Deeb, A.; Kotb, M. Heterocycles 2004, 63, 1143. http://dx.doi.org/10.3987/COM-03-9960

24. Wang, Y.; Lowe, P. R.; Thomson, W. T.; Clark, J.; Stevens, M. F. G.; Chem. Commun. 1997, 4, 363 . http://dx.doi.org/10.1039/A606159A

25. Sadchikova, E. V.; $\quad$ Bakulev, V. A.; Subbotina, Ju. O.; Privalova, D. L.; $\quad$ Dehaen, W.; Van Hecke, K.; Robeyns, K.; Van Meervelt, L.; Mokrushin, V. S. Tetrahedron 2013, 69, 6987.

http://dx.doi.org/10.1016/j.tet.2013.06.062

26. Rusinov, V. L.; Myasnikov, A. V.; Pilicheva, T. L.; Chupakhin, O. N.; Kiprianova, E. A.; Garagulya, A. D. Pharm. Chem. J. 1990, 24, 52. 


\section{http://dx.doi.org/10.1007/BF00769387}

27. Karol, T. J.; Tepper, R. J. U.S. Patent 6489484 B1, 2002.

28. Pinto, D. J. P.; Quan, M. L.; Woerner, F. J.; Li, R. U.S. Patent 2002/119986 A1, 2002.

29. Carrol, F. I.; $\quad$ Kuhar, M. J.; $\quad$ Boja, J. W.; Lewin, A. H.; $\quad$ Abraham, P. U.S. Patent 2003/23090 A1, 2003.

30. Hell, S. W.; Belov, V. N.; Boyarskiy, V. P.; Wurm, C. A.; Jakobs, S.; Geisler, C. U.S. Patent 2012/202216 A1, 2012.

31. Imanishi, Y.; Awai, N.; Hirai, M.; Hosaka, T.; Kono, R. Patent WO 2005/37271 A2, 2005.

32. Rowbottom, M. W.; Faraoni, R.; Chao, Q.; Campbell, B. T.; Lai, A. G.; Setti, E.; Ezawa, M.; Sprankle, K. G. et al. J. Med. Chem. 2012, 55, 1082.

http://dx.doi.org/dx.doi.org/10.1021/jm2009925

33. Bakulev, V. A.; $\quad$ Efimov, I. V.; $\quad$ Belyaev, N. A.; Zhidovinov, S. S.; Rozin, Yu. A.; Volkova, N. N.; Khabarova, A. A.; El'tsov, O. S. Chem. Heterocycl. Compd. 2013, 48, 1880. http://dx.doi.org/10.1007/s10593-013-1225-1

34. Beryozkina, T. V.; Zhidovinov, S. S.; Shafran, Yu. M.; Eltsov, O. S.; Slepukhin, P. A.; Leban, J.; Marquez, J.; Bakulev, V. A. Tetrahedron 2014, 70, 3915. http://dx.doi.org/10.1016/j.tet.2014.04.015

35. Al-Omran, F.; El-Khair, A. A. J. Chem. Res. 2006, 1, 6. http://dx.doi.org/10.3184/030823406776331223

36. Krantz, A.; Laureni, J. J. Am. Chem. Soc. 1977, 99, 4842. http://dx.doi.org/10.1021/ja00456a060

37. Agilent. CrysAlis PRO. Agilent Technologies, Yarnton, England 2011.

38. . Sheldrick, G.M. Acta Crystallogr., Sect. A 2008, 64, 112. http://dx.doi.org/10.1107/S0108767307043930

39. Dolomanov, O. V.; $\quad$ Bourhis, L. J.; $\quad$ Gildea, R. J.; $\quad$ Howard, J. A. K.; $\quad$ Puschmann, H. J. Appl. Cryst. 2009, 42, 339. http://dx.doi.org/10.1107/S0021889808042726 